\title{
CRISE DO CAPITAL, FINANCEIRIZAÇÃO E EDUCAÇÃO
}

\author{
CRISIS DE CAPITAL, FINANCIALIZACIÓN Y EDUCACIÓN
}

\section{CAPITAL CRISIS, FINANCIALIZATION AND EDUCATION}

DOI: http://dx.doi.org/10.9771/gmed.v11i3.36453

Virgínia Fontes ${ }^{1}$

Para este Volume 11, n. 3 de Germinal: Marxismo e Educação em Debate convidou Virginia Maria Gomes de Mattos Fontes, historiadora formada pela Universidade Federal Fluminense e com Doutorado em Filosofia pela Université de Paris X, Nanterre (1992). É docente da Escola Nacional Florestan Fernandes-MST e Coordenadora do GT História e Marxismo - Anpuh, tendo produzido obras de relevância para o reconhecimento da conjuntura com destaque para a inserção brasileira no capitalismo mundial. Entre estas, destacamos: Reflexões Im-pertinentes (2005); O Brasil e o capital-imperialismo: teoria e história (2010); ou os artigos "A incorporação subalterna brasileira ao capital-imperialismo" publicado na Critica Marxista (São Paulo, v. 36, p. 103-114, 2013); “Capitalismo, Crise e Conjuntura”, Revista de Serviço Social (n. 130, São Paulo, set./dez. 2017). Nos auxiliaram na produção do roteiro os Professores Elza Margarida de Mendonça Peixoto, Pedro Leão da Costa Neto, Maria de Fátima Rodrigues Pereira, José Claudinei Lombardi, Nivia de Moraes Bispo, Elson Moura Dias Junior, Otávio Aranha, Vania de Moraes Lopes e Itamar Sousa.

Germinal.: É possível apresentar em poucas palavras a caracterização do capitalismo em vigor no século XXI? Quais as principais diferenças com o que Marx reconheceu na segunda metade do século XIX e o que existe hoje no século XXI?

Virgínia Fontes: Antes, preciso ressaltar a atualidade do pensamento de Marx para, na sequência, apontar brevemente os desafios que envolvem o capitalismo contemporâneo. Marx era um pensador e um estudioso extremamente arguto. Suas contribuições permanecem - a meu juízo - válidas para o nosso tempo. Ele analisou o cerne da condição de base (expropriações e acumulação) e da forma social de existência do capital e do capitalismo, a extração de mais-valor. Marx trabalhou numa dimensão múltipla, com ênfase para um âmbito abstrato muito extenso, capaz de abranger as conexões centrais de fenômenos múltiplos. Vale entretanto lembrar que o mais alto nível de abstração marxiano jamais deixa de lado o aspecto concreto e crucial que constitui o capital, ou seja, a exploração do 
trabalho vivo pelo trabalho morto no processo de troca sociometabólica entre as sociedades e a natureza. Em outros termos, mesmo na mais alta abstração, o concreto precisa estar presente, como condição de existência e de reprodução do capital, ainda que se apresente em suas formas mais complexas e aparentemente descoladas do processo imediato da produção (como o capital fictício). Também no que concerne ao Estado capitalista, as formulações de Marx seguem fundamentais, pois a universalidade aparente de que se reveste o Estado é o aval da manutenção da ordem capitalista. Tanto no terreno da extração de valor, quanto no que concerne aos direitos (sociais, civis, políticos, trabalhistas, etc.), a luta de classes é indissociável do capital, pois não há capital sem exploração do trabalho. Sem Marx, é impossível analisar o capitalismo contemporâneo. Se houve vários momentos históricos de alguma emancipação política através da conquista do direitos, os retrocessos nas últimas décadas reafirmam a exigência de Marx pela emancipação social, pela superação da ordem do capital.

Quanto ao segundo ponto, eu não considero que haja nada de totalmente novo no capitalismo contemporâneo, mas o próprio resultado de sua enorme expansão, que Marx, homem do século XX, não pôde observar. As relações centrais são as mesmas apresentadas por Marx, tanto em sua dimensão concreta da vida dos trabalhadores sob a extração de mais-valor, do crescimento da riqueza das burguesias, pela acumulação centralização e concentração, especulações diversas - e pela subsunção generalizada do trabalho ao capital.

No entanto, Marx não se pretendeu jamais um adivinhador do futuro e sempre exigiu de si próprio a continuidade das pesquisas, das longas investigações para compreender os processos históricos das contradições sociais engendradas pela expansão do capital. Se o cerne é o mesmo, a ampliação do capital na escala atual gera novas tensões, novas contradições ou, senão novas, ampliadas em alguns pontos, exacerbadas em outros e, contidas em outros casos. Marx mostrou isso genialmente em diversos trabalhos, na trilogia sobre as lutas sociais na França, na famosa análise da baixa tendencial da taxa de lucros, que envolve contra-tendências produzidas politicamente, na belíssima troca de cartas com Vera Zassulich, sobre as possibilidades do campesinato russo numa revolução e na crítica do programa de Gotha, dentre outros. Um dos textos interessantíssimos sobre o tema é Salário, Preço e Lucro, onde o processo da luta por salários e por redução de jornada de trabalho é apresentado como fundamental, mas que essas não são sua única finalidade, que deve ser superar o capital. A luta concreta é pois efetiva pedagogia em ação, luta parcial que se abre para o futuro. Assim, compreender e seguir Marx é uma exigência permanente de análise e de síntese da vida concreta sob o capital.

Para além desses aspectos, é importante lembrar que o marxismo é uma corrente de pensamento e de ação extremamente viva e pulsante, e que constituiu diferentes tradições intelectuais e militantes, bastante diversas entre si. Integrando as lutas de classes dos 
séculos XX e XXI, podemos dizer que há marxismos de muitos matizes e nuances, nem todos no mesmo grau de qualidade, de rigor teórico, e de consistência intelectual e política. Vou destacar aqui alguns (há muitos mais) dos clássicos do marxismo, que trouxeram enormes contribuições analíticas e que acrescentaram determinações fundamentais para os militantes e pesquisadores dos nossos dias: Lênin, Rosa Luxemburgo, Leon Trotsky, Antonio Gramsci, Gyorg Lukacs, Edward Thompson... Essa não é uma lista exaustiva, apenas um lembrete de que antes de nós, outros já avançaram nas trilhas da análise do capitalismo contemporâneo, trazendo elementos fundamentais. Tampouco eles esgotam o problema, e também eles exigem que cada geração avance na pesquisa, na organização e na luta social. O capital - o capitalismo somente se supera na prática da luta social.

Com isso em mente, podemos colocar os desafios centrais que se apresentam a todos os marxistas para a compreensão do capitalismo contemporâneo. O primeiro deles e, a meu juízo, é que o capitalismo é um modo de ser contraditório e que suscita contradições antagônicas. A mais importante é o aumento, heterogeneização e intensa socialização das classes trabalhadoras, resultando em aprofundamento de exploração e opressões e, em seguida, a devastação ambiental que promoveu.

O crescimento numérico das classes trabalhadoras - isto é, trabalhadores sem outra opção a não ser a venda da força de trabalho - resulta de diversos fenômenos, dentre os quais: a) a contínua sangria do povo do campo, com a continuidade e o aprofundamento das expropriações primárias; b) o ingresso na produção capitalista de enormes massas de trabalhadores dos países da antiga União Soviética, após o seu desmoronamento; c) o avanço da China para a posição de 'fábrica do mundo', isto é, de massiva força de trabalho produzindo mais-valor, estreitamente conectada com os demais países capitalistas. Isso envolveu formas diferenciadas de expropriação de trabalhadores do campo na China (pois uma parte ainda relevante dos trabalhadores urbanos conserva relações com sua parcela de terra rural) e modalidades diversificadas de contrato de trabalho (há uma quantidade expressiva de trabalhadores sem vínculos formais, ou com variedade de vínculos); e d) enormes expropriações secundárias incidindo sobre as populações urbanas de todos os países, de maneira a redisponibilizá-las para o mercado, desprovidas das conquistas que as classes trabalhadoras haviam assegurado nos últimos 150 anos, como contratos de trabalho, direitos previdenciários, direitos sociais, etc. Essa lista não é exaustiva, apenas procura lembrar que houve enorme crescimento internacional da classe trabalhadora urbana, ao lado da renhida luta dos camponeses e trabalhadores do campo. O segundo ponto importante é a configuração das classes dominantes, dada a escala da centralização e concentração de capitais no mundo contemporâneo, o que redesenha as contradições entre suas diversas frações, tanto nos espaços nacionais como internacionais. Esse é um estudo que precisa estar sempre atualizado, identificando as 
características precisas da propriedade do capital e das tensões entre eles, e envolve enorme diversidade e desigualdade no espectro internacional onde se desenvolve hoje a acumulação. Alguns temas parecem essenciais aqui:

A fração ou setor da propriedade capitalista predominante - esse tema costuma ser polêmico, mas há uma certa generalização que vai muito além do marxismo, gerando um senso comum, sobre a 'financeirização', praticamente designando os "bancos". Como toda generalização, tende a apagar determinações fundamentais. É preciso sempre lembrar que, como o capital é uma relação social - apropriação privada da riqueza natural e da riqueza produzida a partir da extração de mais-valor de trabalhadores "livres" (expropriados e sem acesso aos meios de produção), as diferentes frações do capital são sempre elementos parcelares do capital total que se apropriam de maior ou menor parte do mais-valor produzido. Todos dependem do ciclo completo de valorização do capital e, de maneira nevrálgica, da extração de mais-valor sobre os trabalhadores.

Minhas investigações me levaram a algo próximo, mas em escala muito maior, daquilo que Lênin chamou de capital financeiro, que era a associação "íntima" entre o capital industrial e o bancário. $\mathrm{Na}$ atualidade ela se converteu em fusão pornográfica da grande propriedade, uma das características do capital-imperialismo.

Reconheço e recolho contribuições de várias correntes do marxismo, que enfatizam ora o rentismo, ora o parasitismo das frações dominantes "financeiras", que são questões verdadeiras mas insuficientes. É claro que há rentismo e parasitismo no capitalismo, essa é a própria condição das classes dominantes em diferentes momentos históricos. Classes dominantes são parasitas, mesmo quando tentam mostrar-se como 'empreendedoras', 'inovadoras', 'criadoras de postos de trabalho', etc. O rentismo integra a forma de ser do capital, mas não o esgota nem o explica. Capitais vivem de extorquir trabalho vivo através do trabalho morto cristalizado sob a forma de dinheiro-capital e esse é seu parasitismo primário, mesmo quando é 'produtivo', isto é, quando extrai mais-valia. Quanto ao capital fictício, é verdade que vivemos um período de crescimento monstruoso de enormes quantidades de capital que procuram se valorizar a qualquer custo, e especulam e/ou buscam refúgio em diversas formas fictícias (bolsas de valores, títulos de dívida pública, fraudes diversas, etc.). São massas de recursos que não geram diretamente mais-valor enquanto estão nessas posições, mas é sempre bom lembrar que se apropriam de parcela das riquezas produzidas ou de bens naturais (condição para a extração de mais-valor).

O que tenho procurado compreender é a relação entre a propriedade do capital e o trabalho, entre essas enormes quantidades de capitais (assinaladas pelas duas correntes acima) e as modalidades de extração de mais-valor. Assim, o que procurei analisar foi a conexão entre o processo de crescimento da massa de trabalhadores, expropriados crescentemente pela próprio movimento do capital, e a necessidade incessante de criação de mais-valor a partir da gigantesca centralização e concentração de capitais. Essa 
circunstância gerou formas a cada dia mais perversas de subordinação do trabalho ao capital, através da industrialização de setores que as lutas sociais haviam conseguido retirar (em parte) do âmbito da valorização do valor, especialmente saúde e educação, mas também transporte, cultura, lazer, etc. Volumes gigantescos de capital à procura de valorização atuam como imensos drenos de captura de todas as formas monetárias disponíveis (mercado de capitais) e concorrem entre si de inúmeras maneiras, inclusive pelo rentismo e pelo capital fictício. Mas, sobretudo, atuam como monstruosos impulsionadores da extração de mais-valor, sem nenhuma consideração com a vida humana ou com as atividades que exigem dos trabalhadores, através das formas mais brutais e precarizadas (o que se convencionou chamar de uberização, por exemplo). Convivem modalidades clássicas de assalariamento e de produção fabril com o crescimento da industrialização da educação, através da participação de fundos de capitais na produção de sistemas, de aulas, de materiais educativos; ou com a terceirização massiva do trabalho em áreas como a saúde e os cuidados; ou ainda com o endividamento massivo, que impele ao trabalho sob quaisquer condições e punciona mais valor, além de saquear o próprio trabalho necessário que esses trabalhadores conseguem realizar. São todas modalidades massivas de extração de mais-valor, com total descompromisso dos proprietários do capital das próprias condições de trabalho.

O controle proprietário capitalista final se concentrou em unidades de 'pura' propriedade (holdings e fundos), constituídas e entrelaçadas com bancos, com outras holdings, com fundos dos mais diversos tipos, bancários e não bancários e controlando empresas diversas - comerciais, industriais, serviços, etc. Holdings controlam tanto setores financeiros quanto produtivos dos mais diversos tipos, fundos entram no controle das empresas, reestruturam (demitem) para exigir mais 'produtividade', extorquem o máximo de mais-valor durante algum tempo e, como imensos predadores, saem para procurar novas vítimas. Essa é a forma do capital em sua expansão. Esse processo não se deu de maneira instantânea mas originou-se com a constituição de 'multinacionais' nos anos 1950-60, prosseguiu pela liberação de fluxos internacionais de capitais, seguiu pela expansão de fundos financeiros não bancários e pela constituição de holdings proprietárias, avançou muito nos anos 1970 e, em especial, nos anos 1990 com a abertura da China para a produção associada com capitais internacionais. A compreensão dos setores e/ou frações do capital dominante na atualidade deve levar em consideração sobretudo a escala dessa propriedade e sua interconexão.

Isso nos leva ao segundo tema, que é o da internacionalização do capital. Ora capital não tem pátria, mas depende de Estado! Houve efetiva interconexão entre grandes proprietários de diferentes países, mas em todos os casos essa interconexão conservou e aumentou o peso dos Estados na promoção da violência de classe: internamente, com o aumento da violência policial e jurídica na contenção das classes trabalhadoras 
(encarceramentos massivos, brutalidade policial contra os nacionais); externamente, no crescimento exponencial dos gastos militares, inclusive após o fim da União Soviética, que era apresentada como a 'razão' de tais gastos. Um ponto a considerar é que parcela dos grandes proprietários de capital passaram a curto-circuitar seus próprios Estados através de paraísos fiscais e, com isso, impuseram ainda maior peso de tributação e da sustentação do Estado sobre os próprios trabalhadores. Mas paraísos fiscais não produzem mais-valor... embora sirvam para fraudar impostos. Tampouco garantem forças armadas para defender a 'sagrada' propriedade do capital. Os estados de origem dos capitais continuam a ser o ponto de ancoragem fundamental. Dada a expansão do capital-imperialismo, alguns países centrais (e seus exércitos), com o predomínio dos EUA, passaram a atrair os grandes capitais de países menores, que ali se aninham sob a proteção alheia. Até estourar as crises...

Além disso, a definição das classes dominantes precisa ir além dos proprietários últimos (que são um punhado de multibilionários), e incorporar os proprietários intermediários (alguns muito grandes ou médios) e os empresários-capatazes (ou capitalistas funcionantes), que coordenam diretamente a extração de mais-valor nas mais variadas iniciativas, mesmo não sendo juridicamente os proprietários, como sindicalistas gerindo fundos de pensão, antigos proprietários de escola convertidos em gestores da extração de mais-valor de docentes através da Educação à Distância-EAD para grandes fundos; gestores de recursos públicos privatizados, como as Organizações Sociais, apenas aparentemente sem fins lucrativos; detentores de ações e de títulos da dívida pública, dentre outros. Houve uma redução expressiva do número de proprietários últimos, mas uma ampliação do número de intermediários capitalistas, como consultores, avaliadores, etc.. Finalmente, uma miríade de empresários dirigindo entidades sem fins lucrativos, com funções múltiplas, integra também as classes dominantes. A mais relevante dessas funções é a da contenção das lutas sociais populares por modalidades de convencimento pela via de uma mercantil-filantropia empresarial, assim como aquelas destinadas à formulação e execução de políticas públicas, em âmbitos nacionais e internacionais.

Finalmente, o tema do Estado e das maneiras pelas quais se organizou a dominação de classes, enfrentando as impressionantes lutas dos trabalhadores nos últimos períodos. Os Estados capitalistas tenderam a incorporar mais segmentos subalternos, de um lado, em resposta às pressões populares e mantendo o discurso democrático. Os temas das reivindicações mais urgentes integraram os Estados: racismo, feminismo, xenofobia, ambiente, etc. No entanto, em muitos casos - no exterior e no Brasil - os portadores das reivindicações populares eram representantes do capital mercantil-filantrópico. De outro lado, o cerne central do Estado (as decisões econômicas) foi fortificado, foi blindado, de maneira a que não houvesse nenhuma interferência política popular nesse âmbito. Isso aprofundou a redução da democracia a uma espécie de 'assembleia de acionistas', onde 
minoritários eventualmente têm direito a voz, somente através de alguns representantes autorizados, mas jamais à decisões.

Em resumo, temos um capitalismo altamente concentrado e centralizado, com impacto em todos os recantos do mundo. A tendência que observo é a explicitação da propriedade pura do capital enquanto controle não apenas sobre os meios de produção, mas sobre todos os recursos necessários à produção da existência. O trabalho não acabou, nem acabará sob o capital, embora sua condição concreta esteja piorando ininterruptamente, na proporção inversa da concentração de capitais. A contraposição antagônica da concentração de capitais é uma enorme socialização, porém difusa, na produção de bens, pois massas gigantescas de trabalhadores, em condições e tarefas heterogêneas (do pesquisador de ponta ao trabalhador de telemarketing; das grandes fábricas de componentes eletrônicos aos entregadores de alimentos pedalando bicicletas, etc), participam mesmo sem terem plena consciência disso, da produção coletiva da existência, em escalas nacionais e internacionais. Porém enquanto a riqueza se concentra, as condições de vida de enormes massas da população através do mundo se degrada, gerando crescentes tensões.

\section{G. Quais os fundamentos, quais os critérios para a sustentação da tese de que vivemos uma crise mundial deste modo de produção? Quais os traços fundamentais que diferenciam esta crise das crises de 1929 e 1970, por exemplo??}

$\boldsymbol{V}$. F.: Até muito recentemente, e em especial até a atual crise, que se conectou com a pandemia da Covid19, critiquei muitos autores que insistiam no tema da crise do capital, uma vez que minhas investigações apontavam, ao contrário, para uma extensão, uma ampliação sem precedentes das relaçôes sociais capitalistas e para as dificuldades de articulação das lutas antiimperialistas e anticapitalistas nessa nova escala. É preciso explicar-me bem cuidadosamente, para não gerar confusões.

Capitalismo é um modo de produção e de vida social crítico. Sua dinâmica interna o leva a concentrar massas de capitais que buscam valorização e que estão em crescente concorrência, o que conduz à redução quase generalizada das taxas de lucro e, em alguns momentos, leva a um enorme desabamento, como se fosse um castelo de cartas. São crises recorrentes de super-produção do próprio capital. Como mencionou Marx, “tudo o que é sólido desmancha no ar"... Essas crises, mesmo se destroem empresas ou empobrecem alguns milionários, são muito mais devastadoras para as populações, lançadas na impossibilidade de proverem sua subsistência, inclusive porque o capital saqueia os bens coletivos (bens naturais e os fundos públicos) para recompor-se da crise. Crises econômicas de maior escala contribuem ainda para o acirramento das contradições inter-capitalistas, tendo gerado duas grandes guerras mundiais e uma infinidade de guerras localizadas no século XX, que persistem no século XXI. Porém não se pode esquecer que as crises econômicas estão no DNA do capital e do capitalismo, e que na ausência do enfrentamento ao próprio capital, a tendência é tais crises penalizarem as massas 
trabalhadoras e reconstituírem a dinâmica de expansão do capital, sem nenhuma consideração sobre as condições de vida das maiorias.

Na mesma trilha de Marx, que assinalara a contradição insolúvel entre o capital e o trabalho; e entre a socialização da produção e a apropriação privada de seu resultado, Mészáros genialmente insistiu sobre a devastação da natureza e a ruptura sociometabólica imposta pelo capital, assim como apontou para novas contradições insuperáveis para o capital, como a plena incorporação das mulheres e de suas revindicações, além do risco de uma hecatombe nuclear. O que ele assinalava não era exatamente uma crise 'do capital', mas seguidas crises sociais e econômicas impostas pelo capital sobre a humanidade, para as quais o capital não tem como assegurar saídas a não ser devastando ainda mais as condições de reprodução da própria vida.

Mais uma vez, trata-se de identificar as contradições que impulsionam em direção à superação desse modo de produção e de ser, e agir para gerar uma efetiva crise do capital.

Vivemos recentemente uma enorme crise de superprodução de capital, iniciada nos EUA em 2008 e continuada na Europa, desde 2009 (Grécia, Espanha, Irlanda, Itália), aprofundada a partir de 2011-12. Vimos como toda a dogmática que sustentava os capitais funcionou desigualmente, punindo os países pobres com o dogma austericida, mas rapidamente 'virando a casaca' com os grandes capitais, injetando trilhões de dólares para os grandes proprietários, considerados 'grandes demais para quebrar'.

Esse procedimento procurou evitar uma enorme destruição de capitais de todos os tipos (a começar pelos especulativos), mas aprofundou a exploração das classes trabalhadoras. Deslocou os recursos públicos para salvar grandes empresas e bancos, mas deixou a dívida pública a ser cobrada das massas de trabalhadores, que viveram nas últimas décadas uma exploração das formas precarizadas de trabalho e eliminação de direitos. O resultado é que as condições geradoras da crise continuaram intactas superprodução de capitais, o que tende a reduzir a lucratividade média de todos eles, e intensificação das condições de precarização das massas trabalhadoras. Estávamos assistindo a uma escalada internacional da extrema direita, como nos EUA, Inglaterra e até mesmo de formatos proto-fascistas, como o caso brasileiro.

Esta vem sendo a forma para tentar conter massas populares, reativando medos, xenofobias, racismos, supremacismos, etc. Não há promessas, não perspectivas de futuro ou de melhorias. Aposta-se na fanatização e na violência. O uso de comunicação direcionada (redes sociais, especialmente whatsapp) para intimidação, ameaças, disseminação do medo e da violência é um de seus aspectos. Expressa processos de fascistização interna, mas mostra também o aumento de tensões internacionais.

$\mathrm{Na}$ crise econômica iniciada em 2019, os governos do capital pretendem repetir exatamente o mesmo procedimento anterior. Não obstante, há um elemento diverso, que é a condição sanitária que se superpõe à atual crise econômica. O coronavírus não é causador da crise econômica, mas apenas seu detonador. As evidências sociais, em âmbito internacional, da precarização da saúde pública, da fragilidade dos trabalhadores precarizados diante de quaisquer eventos sanitários maiores, o escândalo do deslocamento de recursos públicos gigantescos para o grande capital, o avultamento do desemprego, tudo isso tem efeitos políticos relevantes e um deles é o crescimento internacional da 
reivindicação de que a vida deve estar antes e acima do lucro, isto é, do capital. Novas exigências sociais começam a se opor a essa violenta extração de direitos em plena crise, com o direcionamento de recursos públicos gigantescos para os grandes capitais, além de ainda maior precarização dos trabalhadores, através de demissões e cortes de salários.

A crise recorrente do capital estava para se abater sobre o mundo. A forma desta crise, com seu aspecto sanitário escancarou a tragédia dantesca imposta pelo capital nas últimas década e trouxe a defesa da vida como reivindicação popular, contraposta pelo capital à defesa da "economia" (leia-se a defesa dos lucros). Isso indica a possibilidade de uma retomada de lutas de classes muito agudas nos próximos anos, explicitamente questionando as relações sociais capitalistas no seu âmago, que é o desprezo pela vida das massas populares.

A superposição da crise econômica com a crise sanitária pode permitir enfeixar esse conjunto de contradições na proposição popular que defende 'a vida acima do lucro e do capital' e a que é defendida pelas direitas, 'a economia e o lucro antes da vida'. Ela abre nova possibilidade no cenário nacional e internacional. Mas dependerá de enormes lutas.

G. Como você analisa a ferocidade do avanço do capital e de grupos conservadores sobre o poder de Estado e o particular ataque aos direitos sociais, às políticas sociais, à educação pública na forma da educação básica e da educação superior? Qual o impacto destes ataque sobre a vida dos trabalhadores e dos grupos mais frágeis (mulheres, jovens, idosos, crianças)? Há resistência? Onde?

V.G.: Essa pergunta é fundamental. A extrema concentração e centralização do capital impulsionou o aumento das expropriações primárias e secundárias, gerando maior concorrência - imposta pelo capital - entre os trabalhadores nos âmbitos nacionais e internacionais, piores condições de vida e aumento brutal das desigualdades. As lutas sociais não arrefeceram, embora com maior dificuldade de coordenação: lutas feministas, anti-racismo, lutas contra opressões e segregações (LGBT e defesa de estrangeiros), lutas de bairros (favelas e bairros populares), lutas ambientais, etc., cresceram em todo o mundo e no Brasil.

As burguesias não ficaram inertes diante delas. A constituição de malhas de aparelhos de hegemonia empresariais (entidades associativas sem fins lucrativos) voltavam-se em três grandes direções: defender interesses econômicos, políticos e jurídicos do grande capital; estabelecer o enfrentamento ao pensamento crítico a partir da preparação de quadros no interior de think tanks ou de formações privadas oferecidas por Fundações empresariais e, finalmente, disseminar enorme quantidade de aparelhos de hegemonia voltados para agir diretamente junto a determinados segmentos da população, propondo minorar o sofrimento que... o próprio capital produzia, em processo que chamei de mercantil-filantropia. Há importante entrelaçamento entre entidades de origens diversas (nacionais e estrangeiras) para interferir nas lutas internacionalistas dos trabalhadores (ou de cunho 
popular), as quais também promoviam formas associativas (aparelhos de contra-hegemonia) populares para interferir em 'micro-lutas' nos diferentes países.

Há um certo paralelismo entre o processo de centralização e concentração do capital, sua ação econômica e política e sua atuação nessa malha difusa de entidades associativas mercantilfilantrópicas, uma vez que elas próprias agem reduzindo os direitos cujas consequências anunciam minorar. Esse foi o papel das Parcerias Público-Privadas, das Organizações Sociais, etc.

No Brasil, o maior destaque é para entidades como o Todos pela Educação ou o GIFE-Grupo de Institutos e Fundações Empresariais, que agrupam enorme quantidade de outras entidades empresariais (todas sem fins lucrativos). Os Aparelhos privados de hegemonia empresariais-APHE agiram incessantemente no sentido de controlar as redes públicas existentes e de implantar sistemas de gestão privado e materiais educativos que, não por acaso, algumas das empresas controladoras dos APHE vendiam... Inclusive da Rede Globo, cuja empresa participa do APHE ABAG, e sua entidade sem fins lucrativos, Fundação Roberto Marinho, participa diretamente do Todos pela Educação e do Instituto Millenium. Em seu conjunto, esses APHE são muito numerosos e contam com fartos recursos, inclusive imunidades e isenções fiscais, formulam políticas educacionais, políticas para a juventude, para o meio ambiente, políticas para a saúde, para os recursos hídricos ou para as prefeituras e governos de Estados, contando para isso com grandes escritórios de advocacia que as integram. Disseminam uma aparência democrática, e devastam as possibilidades efetivas de controle popular eleitoral, ao introduzir processos de gestão privada no setor público, ao precarizar a sua força de trabalho nas empresas e nos seus APHE (inclusive por voluntariados peculiares) e exigir a precarização equivalente no setor público. Enquanto as empresas-mãe contribuíam financeiramente com os partidos políticos, os APHE formulavam as diferentes políticas que deveriam pautar a vida pública.

Muitos partidos, inclusive de esquerda, apoiaram-se resolutamente nessas redes de APHEs, acreditando no mito liberal da sociedade civil intocada pelo mercado ou pelo Estado, convenientemente esquecidos que numa sociedade de classes não há espaços isolados da dominação de classes. Como exemplo, o Conselho de Desenvolvimento Econômico e Social do governo Lula foi composto majoritariamente por APHEs, enquanto o Todos pela Educação chegou a ser o formulador inclusive da política oficial para a educação pública dos governos Lula e Dilma. Isso sem mencionar o volume de recursos públicos destinados à educação e saúde privadas NO bRASIL, que se expandiram exponencialmente, sob novas modalidades de centralização e concentração através da participação de fundos, no século XXI.

Corporações (bancos e grandes empresas ou grandes proprietários) impõem exigências políticas de austeridade para a sociedade, enquanto seus APHEs minavam por dentro a democracia, numa operação similar às religiosas, de conversão: apoiavam adversários aparentes, alteravam seus vocabulários inventando uma novlíngua peculiar (eivada de pobretologia), corroíam as defesas populares, amansavam partidos originados nas massas trabalhadoras mas desprovidos de teoria crítica e de análises lastreadas nas classes sociais. A grande maioria desses partidos descambou para políticas 
de minorar sofrimento, meramente compensatórias, propagandeadas e endossadas também pelos organismos internacionais como Banco Mundial.

Essa aparência de 'plena dominação pelo consenso' embora tenha elevado às alturas a mitologia liberal através do elogio à filantropia, ao 'mérito', 'esforço', ao 'empreendedorismo', jamais reduziu a violência pública e, muito menos, a violência paralela, levada a efeito por polícias, seguranças privados e por milícias.

As contradições da vida concreta entretanto cresciam, e as tensões populares rondavam as esquinas, expressas em greves, reivindicações salariais, em movimentos sociais feministas, anti-racistas, antimachistas e anti-sexistas, em lutas ambientais, lutas estudantis, lutas indígenas, etc. A expropriação de direitos, o rebaixamento das condições de trabalho ao lado da concentração da riqueza, frutos da dinâmica capitalista e da atuação de empresários/empresas e APHEs apontavam para situações a cada dia mais complexas, em cidades superlotadas e em agressões a cada dia mais violentas sobre os povos do campo.

De onde vem a extrema direita? No cenário internacional, e em especial nos EUA, a extrema direita cresceu por dentro do próprio liberalismo, intransigente a qualquer direito social e agressiva no enfrentamento a quaisquer reivindicações (dos falcões de Reagan à atual alt-right de Trump). Apesar de grupos novos e agressivos - como a Sociedade do Mont-Pelérin - recuperavam traços ancestrais do pensamento liberal, desfazendo-se de todas as aquisições mais ou menos democráticas.

No caso brasileiro, há vários estudos excelentes a respeito, mas ainda carecemos de sínteses substantivas. Vale lembrar que ela jamais desapareceu e que os organismos - sobretudo os repressivos - de Estado estão eivados de um anticomunismo primário, fomentado pela proximidade jamais reduzida com organismos de Estado dos EUA, com extrema influência em Forças Armadas e polícias na América Latina, como a antiga Escola das Américas, cursos realizados no DoJ - Department of Justice dos EUA, ou diretamente com a CIA. Ademais, no caso brasileiro, a atuação em APHEs nacionais ou internacionais moldados pelos grandes capitais internacionais foi um dos moldes da dominação empresarial, como por exemplo, a AMCHAM e a criação de instituições públicas locais a partir de missões internacionais (anos 1950) ou de sua cópia nas décadas seguintes. As entidades de tipo mercantil-filantrópico apesar de se multiplicarem aqui rapidamente, enfrentaram limites, e até empresários do GIFE se queixam de sua escassa tradição no Brasil. A tradição de truculência no enfrentamento da questão social jamais desapareceu ou foi substantivamente reduzida, mesmo quando doses massivas de 'convencimento' foram empregadas.

É possível indicar que parcela da mesma grande burguesia que financiava procedimentos mercantilfilantrópicos nutriu grupos de extrema direita, começando por agressiva defesa de um liberalismo impiedoso (à la Routhbard, que aliás conta com um instituto no Brasil) e chegando a grupos ainda mais intolerantes.

No Brasil, no momento da emergência de lutas por direitos, em 2013, cujas reivindicações eram de cunho democrático mas vocalizavam os limites dos governos para o capital (exigiam saúde e educação 'padrão Fifa'... e vemos o quanto tinham razão!), se revela de maneira clara a tentativa de 
enfrentamento violento exercida por gente treinada militarmente (militares? Soldados? Paramilitares?) com equipamentos de luta, agressões a partidos, etc. A grande mídia silenciava sobre os que agrediam a vida, mas entoou em uníssono a condenação aos que atacavam símbolos do capital, como se fossem "vândalos". O governo de Dilma Rousseff não foi capaz de coligar-se a elas; tampouco o PT e suas organizações congêneres sindicais, perdendo enorme apoio popular.

As burguesias de todos os portes e linhagens alinharam-se à atuação da Rede Globo que, repito, silenciava sobre a extrema direita emergente enquanto tentou capturar as lutas legítimas para adequálas ao grande capital. E o caminho encontrado foi revelado em 2014, com a peculiar parceria entre a Globo e a operação Lava-Jato.

A meu juízo, os enfrentamentos iniciados em 2013, sem que a juventude em luta encontrasse direção sólida em escala nacional para atingir suas reivindicações e consolidar formas organizativas, resultaram dramaticamente na exacerbação de um ativismo de extrema-direita cuja direção indicava aumento da violência e certa redução das atividades de convencimento, que se deslocavam dos setores populares para os setores médios.

Havia (e segue havendo) contradições inter-burguesas crescentes, uma vez que nem todos os setores das classes dominantes apoiavam a extrema-direita, e que parcela da mega burguesia brasileira internacionalizada entrou quase imediatamente no alvo da Lava-Jato. Isso trouxe uma espécie de divisão de águas entre as as classes dominantes, algumas mega-burguesias mais favorecidas pelos governos PT sob o ataque, enquanto o maior números de empresários, de menor porte e mais distantes dos faraônicos recursos destinados a algumas 'campeãs', se arvorava em 'defensores da moralidade' e da... democracia, desde que voltada para eles. Não é possível entrar aqui em detalhes, mas julgo ser ao longo desse processo, mas em ritmo acelerado, que se reencontram a extrema direita proto-fascista, a direita ultraliberal e alguns movimentos religiosos (católicos e neopentecostais), visível no golpe do impeachment de Dilma Rousseff. No golpe contra Dilma e sob o governo Temer, a eles se agregariam também rapidamente os militares, dada a instabilidade crescente, liderados por sua parcela mais reacionária e mais próxima da doutrina de Segurança Nacional que nutriu o golpe empresarial-militar de 1964 e a ditadura subsequente.

Não se resolvia nenhuma tensão social, ao contrário, ela se aprofundava. Os conflitos intra classes dominantes se agudizavam, sem haver caminho político pavimentado. As burguesias 'democráticas' dos APHEs mercantil-filantrópicos haviam destruído as opções propriamente políticas e, naquela ocasião, recuaram. A moeda de troca capaz de unificar o conjunto díspar das classes dominantes era o aprofundamento da expropriação de direitos, de captura dos recursos públicos, que seriam direcionados também para os setores médios e grandes, e não apenas para os mega-proprietários (rurais e urbanos). Estes ficaram diante da insustentável posição de preservar seus privilégios únicos (ainda sob ataque da Lava-Jato) ou juntar-se ao golpe e tentar uma fuga para a frente de tipo desesperado e anti-popular até a medula. E foi o que fizeram.

As direitas brasileiras e parcela das mega burguesias ainda imaginavam que teriam um caminho político possível, com o retorno ao PSDB, mas este também implodiu no percurso. Aécio Neves, 
protagonista de cenas grotescas contra o governo Dilma Rousseff, mostraria seu lado ainda mais escabroso no transporte de maletas abarrotadas de dinheiro. Geraldo Alckmin fracassou e a prisão de Lula arquitetada pela Lava-jato desmantelou o restante da estrutura parlamentar de representação. O conjunto de tais processo abriu a via para a abominável figura de Bolsonaro, com o apoio aberto ou discreto de todo o conjunto da burguesia brasileira (com raríssimas exceções). No entanto, a linha de frente do bolsonarismo não era constituída pelas grandes e mega fortunas, mas pela mesma linhagem de médios e aspirantes a grandes empresários. As grandes e megas burguesias de todas as áreas rapidamente alinharam-se ao bando, para assegurar seu sempre maior quinhão. Evidenciava-se a ausência de qualquer projeto substantivo de nação a esse conjunto de forças, cujo único objetivo é... "meu pirão primeiro".

Tentando resumir, há um pano de fundo internacional e particularidades brasileiras na emergência do proto-fascismo. Em comum, a constituição de gigantescas massas trabalhadoras, submetidas a formas de extração de mais-valor diversificadas, mas tendencialmente precarizadas e distanciadas das modalidades clássicas organizativas das classes trabalhadoras. Se isso dificulta a luta desses trabalhadores, também oferece um obstáculo para as formas clássicas de contenção utilizadas pelas burguesias, sendo a mais importante delas a ameaça de demissão. O que isso vale diante de massas sem contratos?

As peculiaridades brasileiras são conhecidas, a começar pelo desmantelamento rápido e avassalador da estrutura de representação eleitoral e, com ela, do Partido dos Trabalhadores, a partir do golpe de 2016. Em parte, a política de 'coalizões' do PT e de aprendizado das formas predominantes entre os partidos tradicionais, assim como sua aparente nova proximidade com as classes dominantes contribuiu para reduzir substantivamente a capacidade organizativa dessas enormes massas populares e trabalhadoras. Elas experimentaram, sem dúvida, melhoras em suas condições de vida através de políticas compensatórias ou de financiamentos educativos, com melhoria salarial durante certo período e, ainda com algumas políticas sociais, como o Minha Casa Minha Vida, que fornecia habitações populares modestas e altos lucros para os empresários. Mas ao custo de enorme retrocesso organizativo e de sua formação (ou educação) para uma política de enfrentamento ao capital. E ao custo do aumento das forças repressivas (Força Nacional e as diversas GLO - Garantia da Lei e da Ordem)...

Outras características da sociedade brasileira são o racismo entranhado, o machismo como forma de ser corriqueira, a truculência social como herança da colonização escravista, o frágil enfrentamento político aos grupos civis e militares remanescentes da ditadura empresarial-militar de 1964 e o comportamento predatório das burguesias brasileiras.

Aqui chegamos no ponto crucial, que terá enorme peso na sequência histórica - a renovação e modernização dos "jagunços" na vida rural e urbana brasileira. Em primeiro lugar, as milícias que se converteram em 'empreendedores' que controlam territórios e vivem da exploração direta da miséria de grandes parcelas da população, através da venda de serviços ilegais (água, gás, transporte, especulação imobiliária, construção civil, etc.), da realização de chantagem para vender 'segurança' 
em bairros populares e de classe média. Além de 'planejaram' e venderem assassinatos, como revelado no caso do "Escritório do Crime" e da execução de Marielle Franco e de Anderson Gomes, em conexão com parlamentares e com empresariados de porte diverso. Seu controle territorial a leva a aproximar-se ou afastar-se (expulsando) de igrejas e militantes sociais dessas regiões, filtrando os grupos políticos sob ameaças as mais diversas e a entrar em acordos ou enfrentamentos com grupos ligados ao tráfico de drogas.

Tais milícias têm uma longa história rural e urbana, e vale lembrar que ao longo de todo o século XX aprofundaram-se suas relações com setores policiais (que realizam "bicos" ou "expedientes" para elas, ou mesmo as organizam em horas de 'folga') e com setores políticos, como foi evidenciado pela CPI da milícias realizada no Rio de Janeiro em 2008, sem que tenha ocorrido uma averiguação para a situação nacional. Acrescente-se a prática urbana, nas grandes cidades, de contratar 'empreendedores' avulsos (policiais da ativa, ex-policiais, ou milicianos) para controlar entradas de ruas, fazer vigilância noturna, etc.

Para além desse já numeroso grupo armado e, em parte, conectando-se com ele, há enormes contingentes de empresas de modernas seguranças privadas, a serviço de proprietários rurais, urbanos e de empresas, muitas vezes lideradas - ilegalmente - por policiais ou soldados na ativa que, assim, apresentam-se como 'empresários' 'empreendedores'...

Contingentes massivos de homens armados circulam pelas cidades e campos, legais ou ilegais, mais próximos ou mais distantes dos setores policiais, com o respaldo do silêncio não apenas dos parlamentoso e das burguesias, mas de boa parcela das classes médias.

Mas ainda há mais. A existência de um núcleo envelhecido mas ativo de militares de extrema direita abriu as portas dos quartéis para Bolsonaro e seu empreendedorismo miliciano e policial, sedutor para os praças. Esse é o núcleo central do proto-fascismo brasileiro, grupos armados, produtores de insegurança para vender uma falsa segurança.

Sua proximidade com certos pastores neopentecostais ou padres católicos de extrema-direita parece repousar sobretudo no 'empreendedorismo' comum - todos pretendem controlar territórios, assenhorear-se de certos grupos sociais e assegurar suas fontes de recursos.

Há resistência, e ela está em todos os lados e em todos os setores. Está nos campos, está nos sindicatos, está nas favelas, nas mulheres, no movimento contra o racismo e em defesa dos negros, na luta contra o encarceramento massivo, nas mães que reclamam do assassinato de seus filhos, na luta nas cidades por alimento e água limpas, etc. Resistir é fundamental, mas insuficiente, é preciso enfrentar esse conjunto de contradições. E só há uma maneira, a meu juízo, é enfrentando o conjunto da sociabilidade capitalista. E consolidando laços de confiança entre organizações múltiplas que têm clareza de que o enfrentamento ao capital é essencial, superando na teoria e na prática os limites que os últimos períodos não foram capazes de superar. 


\section{G.: Como a formação social brasileira se insere neste capitalismo em crise? Quais os reais impactos da atual crise econômica na formação social brasileira?}

V. F.: A atual crise econômica, iniciada em fevereiro/março de 2020 já é agora e será ainda mais catastrófica. As crises econômicas vividas no século XXI no Brasil foram de menor monta do que em outros países. Isso não empalidece o fato de que o Brasil, com as enormes desigualdades históricas que suas classes dominantes fazem questão de preservar, vive crises sociais permanentes, de intensidade e gravidade dificilmente comparáveis com outros países. O Brasil contemporâneo foi moldado por dentro do capital-imperialismo. As classes dominantes miravam os Estados Unidos e o centro do capitalismo, mas ajustavam-se aos seus papéis subalternos, de classes dominantes prepotentes internamente, com uma fração altamente concentrada buscando novas formas de convencimento e de drenar recursos públicos tanto de maneira direta (subsídios e políticas) como de maneira discreta, via aparelhos privados de hegemonia empresariais-APHEs, mas subservientes nos espaços internacionais. Desde os anos 1970, intensificado nos anos 1980 e, em especial, a partir de 1990, parcela das classes dominantes brasileiras exportam capitais e aspiram a tornar-se parceiras subordinadas - dos grandes conglomerados internacionais.

A constituição do BRICS o demonstra. Não havia nenhuma intenção - e nem há, todavia - de enfrentar a estrutura capital-imperialista, mas sim a vontade de serem aceitos no clube central capitalimperialista, de tornarem-se sócios plenos da exploração internacional do mais-valor. E isso, independentemente da enorme variedade cultural, histórica e política dos países integrantes da sigla. A reação estadunidense foi severa, mas utilizando-se dos seus canais clássicos de pressão (multas e punições às empresas) e, antes mesmo de quaisquer sanções ou problemas políticos com os EUA, não só as classes dominantes recuaram, como os governos brasileiros. É possível supor que, após a posse de Trump, tenha ocorrido pressões diretamente sobre as Forças Armadas, envolvendo fornecimento de material bélico e peças de reposição.

Infelizmente, mesmo os governos do PT tão louvados por sua política externa, agiram de maneira dupla. De um lado, reproduziram as mesmas práticas imperialistas com os países para os quais exportavam capitais: belas palavras de amizade entre os povos, para disfarçar o avanço brutal da exploração de matérias-primas, de devastação da natureza, de expropriação do campesinato e de trabalhadores diversos, sem falar que os empréstimos realizados não chegavam nos tomadores locais (geralmente governos), e eram pagos diretamente às mega-empresas brasileiras. De outro lado, a aceitação da subserviência através das remessas para paraísos fiscais, do lançamento de ações nas bolsas estadunidenses, colocando empresas estratégicas sob legislação estrangeira. Sem falar da dívida pública e da defesa - acima de tudo - dos interesses de seus proprietários. Os bilionários brasileiros seguem exportando capitais, nem que seja para paraísos fiscais. Enganam-se, entretanto, se imaginam que serão protegidos ou defendidos por governos estrangeiros, e fiam-se nas palavras de amor oportunista de Trump, que não terá nenhum problema em neutralizar o sócio subalterno. 
A crise atual, aberta em 2020, é de grandes proporções e de duração e contornos imprevistos. E nos encontrará em condições muito difíceis, dada a destruição importante nas últimas décadas de produção variada para o consumo local, o envenenamento de águas, terras e ares com agrotóxicos para nutrir um agronegócio exportador cujo maior importador (a China) parece tornar-se o inimigo principal do próprio governo brasileiro. Com a educação, a saúde e a ciência combalidas, com um passivo brutal de infraestrutura sanitária, de água potável e de saneamento.

As tendências anteriores a essa crise mostravam um crescimento de formas políticas truculentas, seja por governos com tendências proto-fascistas (Brasil, Estados Unidos, Filipinas, Hungria, Itália, Israel, etc.), seja pelo crescimento da truculência policial e militar, voltada contra as populações, como na França, contra os coletes amarelos, e no Chile, indiscriminadamente.

As contra-tendências internacionais apontam para uma reivindicação crescente de democratização substantiva e de participação plena nas decisões políticas, com fortes críticas a partidos e setores parlamentares que se dobram facilmente às imposições empresariais. As lutas sociais atingiram setores sociais inusitados, como na Argentina, no Chile e na França.

Repito - o caráter sanitário da atual crise abre uma questão de âmbito internacional para as classes trabalhadoras: a vida deve estar acima dos lucros e do capital. Isso quer dizer que, diferentemente das crises econômicas de 2008 e de 2012, não é garantido que os grandes capitais logrem apoderar-se de recursos e dívidas públicas impunemente, como estão fazendo nesse período escudando-se sob o coronavírus. Essa situação aponta para a intensificação de lutas sociais, por enquanto algo contidas pelo isolamento social imposto pela pandemia. As greves 'selvagens' na Europa, as reivindicações de definição precisa do que é 'trabalho essencial', as lutas por equipamentos proteção muito além do pessoal da saúde, mas de todos os que continuam a trabalhar mostram que as reivindicações de igualdade cresceram. O caso atual dos Estados Unidos, o país mais rico do mundo em plena crise sanitária, com fossas comuns, corpos em frigoríficos e enfermeiros vestidos com sacos de lixo, demonstra o descaso frente aos trabalhadores e suscita escândalo local e internacional.

No Brasil, ao longo da crise as tendências fascitizantes e/ou autocráticas cresceram, e a todo dia temos novas ameaças de golpe entre os próprios setores institucionais, como a presidência protofascista, que age pela mobilização e agitação de cunho miliciano e/ou as Forças Armadas, cuja tendência maior conduz a um fechamento ditatorial. As classes dominantes em conluio estreito com o governo extorquem o máximo possível de benefícios, aproveitando-se tanto do isolamento em razão da pandemia, como de um governo cujo único denominador comum é a extração de direitos das grandes maiorias. Não lhes é difícil conseguir a maior parcela do butim, dada a estreita intimidade dos 'investidores' com Paulo Guedes. Um verdadeiro saque aos recursos públicos está em curso. Uma parca quantidade de dinheiro está sendo encaminhada à saúde (pública, mas também privada, que segue lucrando com a tragédia) e gotículas estão sendo prometidas para as grandes massas. Já estão avisando em alto e bom som que quem pagará todas as contas - como sempre - serão as massas trabalhadoras, que ainda se defrontará com o desemprego e a destruição da ciência e da educação públicas. 
Mas a existência das tensões não assegura processos democratizantes ou socializantes, e depende da capacidade organizativa dos trabalhadores com ou sem contratos, partidos e movimentos sociais, além de uma intensa formação durante e na sequência do processo de isolamento, o que é bem difícil de executar em país tão desigual. Não obstante, é previsível uma explosão de lutas populares assim que houver uma redução do isolamento: em função da mortandade que estamos assistindo pelo descaso governamental com a saúde pública - e não só nos hospitais, nos EPIs e nas UTIs, mas na alimentação, saneamento, garantia de moradia e de apoio para essa enorme parcela precarizada; e das perdas familiares e humilhações sofridas durante a pandemia. Que serão agravadas pelo contraste entre os empregadores, que estarão com a faca na mão para extorquir ainda mais os trabalhadores.

Está mais do que evidente que as burguesias brasileiras jamais tiveram e nem terão nenhum compromisso com a população, e se as situações anteriores já o haviam demonstrado, a pandemia mostra seu descaramento.

Não haverá ‘desenvolvimento capitalista' para as maiorias, nem no mundo e muito menos no Brasil. Não poderemos admitir a repetição da adequação de esquerdas para o capital. Seguidas derrotas das organizações dos trabalhadores abriram o passo para uma dinâmica fascistizante, cujo risco maior é falsificação deslavada das reivindicações das massas. $\mathrm{Na}$ ausência de posições anticapitalistas claras, é o protofascismo quem se apresenta como se estivesse contra "tudo isso o que está aî", quando não passa da sua continuidade piorada, agravada por práticas anti-populares, por corrupção no seu mais alto grau, e de oportunismos mais diversos travestidos de falas moralizantes.

Já estamos vivendo duríssimas lutas e elas deverão se intensificar nos próximos períodos.

\section{Qual a sua análise sobre o estágio de desenvolvimento da luta de classes própria da formação} social brasileira? Quais os grupos políticos que perderam força e ascenderam? Especialmente, quais os impactos da ascenção dos grupos políticos por trás do Governo de Bolsonaro ao poder de Estado? Por que a aliança em torno do Projeto Democrático e Popular perdeu força e desfez-se? Quais os desafios para a esquerda que decorrem desta movimentação no interior da luta de classes?

$\boldsymbol{V}$. F.: Em Gramsci, um projeto democrático-popular significa a organização concreta dos subalternos para enfrentar os processos de dominação do capital em seus múltiplos aspectos. Significa o predomínio da grande política (a que envolve visões de mundo e a organização dos processos de produção) frente à pequena política, aquela que se limita aos ajustes cotidianos das formas de dominação burguesa. Envolve formação ético-política do partido e das grandes massas, envolve organização popular crescente, formação de lideranças e participação ampliada nas decisões de todas ordens - a começar pelas econômicas, mantidas a sete chaves sob controle das classes dominantes.

O projeto democrático-popular de vaga inspiração gramsciana, portado pelo Partido dos Trabalhadores, já não era muito sólido teoricamente e desvirtuou-se rapidamente, primeiro sob o impacto da queda da URSS, e, na sequência sob o peso do projeto desenvolvimentista-pobretologista 
levado a efeito e dirigido pelas classes dominantes brasileiras e estrangeiras. Mas pilotado por um partido de origem popular. A diferença entre a intenção e o gesto deve ser avaliada com especial rigor nesse caso. Um projeto ético-político no sentido gramsciano é, em seus próprios termos, um momento da 'guerra de classes' e envolveria a criação (ou o reforço) de um partido de novo tipo (um novo príncipe), criador da sua própria prática a partir de sólida formação teórica, desvencilhando-se das hierarquias burguesas, promotor de uma nova sociabilidade na qual a socialização do conhecimento seria um dos elementos fundamentais; onde as organizações populares reforçassem sua autonomia de classe, com os subalternos acumulando forças para o enfrentamento da dominação de classes. Tal acumulação não se limita a ocupar espaços menores no Estado, embora não possa deles prescindir. Mas exige enfrentar a disputa pela grande política, aquela que põe em xeque as grandes questões estruturais. A disputa de hegemonia, em Gramsci, não significa o fim dos enfrentamentos; ao contrário, supõe que os subalternos, de maneira organizada, consigam impor suas formas de ser e suas práticas aos grupos dominantes e ao Estado. Se para Gramsci as lutas são levadas na sociedade civil, elas exigem e supõem substantivas transformações estatais. Ora, no Brasil, houve uma esterilização da reflexão gramsciana, com um palavrório abstrato que se traduziu apenas - e tragicamente - no endosso edulcorado de contrarreformas brutais, com os partidos supostamente populares mudando seu papel (transformismo, nos termos gramscianos). Falavam de 'correlação de forças', apenas para justificar sua impotência e preservá-la. Deixavam de ser ou aspirar ao 'novo príncipe' e acomodavam-se no papel de gestores, anda que melhor intencionados, do capital. Perderam duplamente: não foram aceitos pelos de cima, que forjam seus próprios gestores e, aliás, os impuseram mesmo nas políticas públicas universais para as quais havíamos acumulado grande histórico de lutas populares, especialmente na saúde e na educação; e perderam sua ligação com as grandes massas trabalhadoras, expropriadas de direitos e crescentemente precarizadas.

O resultado desse transformismo - quando dirigentes das classes subalternas convertem-se em mandatários menos agressivos voltados para minorar os efeitos das determinações impostas pelas classes dominantes - não poderia ser mais trágico no Brasil. Envolveu uma significativa perda da organização sindical dos trabalhadores ainda com contrato, e da construção de sua proximidade e de sua influência sobre os demais trabalhadores não sindicalizados (terceirizados e precarizados); trouxe uma descrença enorme frente a todo e qualquer partido político; reforçou uma desqualificação generalizada das formas de organização próprias da classe trabalhadora, cujos partidos não necessariamente são expressões eleitorais, mas imperativamente precisam ser organizativos. A atuação organizativa mais intensa no século XXI foi, dramaticamente, das grandes burguesias, através de seus APHEs, e conseguiram convencer inclusive o PT. Há muitas e substantivas críticas ao 'projeto democrático e popular', e a maioria tem razão. Analisando seus desdobramentos, ele representou sobretudo a reedição de projetos de conciliação de classe, com ênfase na questão do desenvolvimento econômico, pensado sob o prisma da burguesia - aumento da lucratividade e não da satisfação das necessidades da população, centralização e concentração de capitais e redução dos direitos dos trabalhadores. A crença nas burguesias brasileiras, que já era questão vencida desde o golpe 
empresarial-militar de 1964, retornou ainda mais envelhecida ao ser conduzida um partido que em alguns momentos detinha todas as condições para levar adiante processos muito mais avançados de luta. Mas não o fez. Tornou-se, infelizmente, uma "esquerda para o capital". Essa postura anunciava o pior, e que veio a ocorrer: a adesão de parcela das massas trabalhadoras, órfãs e tendo sua história e suas reivindicações clássicas abandonadas, a impostores fascistizantes.

Os desafios que se colocam agora são gigantescos. O recuo dos sindicatos envolve também a ascensão de grupos oportunistas e prestes a acaparar setores sindicais com ainda algum grau de autonomia; a destruição das conquistas - mesmo se magras - ligadas à reforma agrária, especialmente perversa quando agora intenta destroçar as iniciativas brilhantes de educação do campo; a constatação do aumento da violência estatal (com operações de Lei e de Ordem e com a Força Nacional) e de sua promiscuidade com setores milicianos; o isolamento de muitas favelas e bairros populares, com o acesso quase impedido aos militantes, mas facilitado às igrejas, polícias e milícias, para as quais o mesmo Estado delegou as funções de gerenciar os recursos públicos destinados àquelas populações. Não partimos mais do zero, pois já aprendemos o que não podemos repetir. Mas agora temos de enfrentar prioritariamente grupos fascistas na presidência, no congresso e no cotidiano, grupos apoiados por milicianos sem escrúpulos (inclusive virtuais), além de forças militares que apoiam o atual governo. Temos de lutar em múltiplas fronteiras, reestruturando as nossas bases organizativas, voltando ter análises críticas substantivas, de molde a informar as lutas e não se deixar engabelar nem pelas brutais prédicas protofascistas, nem pela sedução liberal disposta a financiar 'benevolamente' nossas reivindicações. Precisamos redescobrir a importância das massas humanas contra a massa de recursos disposta a corrompê-las. Precisaremos enfrentar o Estado capitalista e não apenas melhorálo.

Não partimos em boas condições nessa crise econômica e sanitária avassaladora que já se implanta. Mas ela nos exige recolocar - novamente - um verdadeiro projeto coletivo, onde a vida esteja acima do lucro - na relação com a natureza e na agroecologia, nas favelas e no redesenho das relações entre campo e cidade, na saúde, na habitação, nos transportes, nas comunicações, em suma, no conjunto da vida.

\footnotetext{
Notas:

${ }^{1}$ Historiadora, com mestrado na UFF (1985) e doutorado em Filosofia - Université de Paris X, Nanterre (1992). Atua na PósGraduação em História da UFF, onde integra o NIEP-MARX - Núcleo Interdisciplinar de Estudos e Pesquisas sobre Marx e o marxismo, e na Fiocruz, Escola Politécnica de Saúde Joaquim Venâncio-EPSJV, onde também coordenou e participa de curso de Especialização. Em atuação conjunta entre Escola Nacional de Saúde Pública-ENSP, a EPSJV e o Ministério da Saúde, coordenou coletivamente e atuou no mestrado profissional "Trabalho, Saúde, Ambiente e Movimentos Sociais". Principais áreas de atuação: Teoria e Filosofia da História, Epistemologia, História do Brasil República, História Contemporânea. Autora de Reflexões Im-
} 
pertinentes (2005), de O Brasil e o capital-imperialismo: teoria e história (2010), e de inúmeros artigos em periódicos nacionais e internacionais. Docente da Escola Nacional Florestan Fernandes-MST. Coordenadora do GT História e Marxismo-Anpuh. Integra diversos conselhos editoriais no país e no exterior. ORCID: https://orcid.org/0000-0002-5689-8249 Email: virginia.fontes@gmail.com 